WORKING PAPER

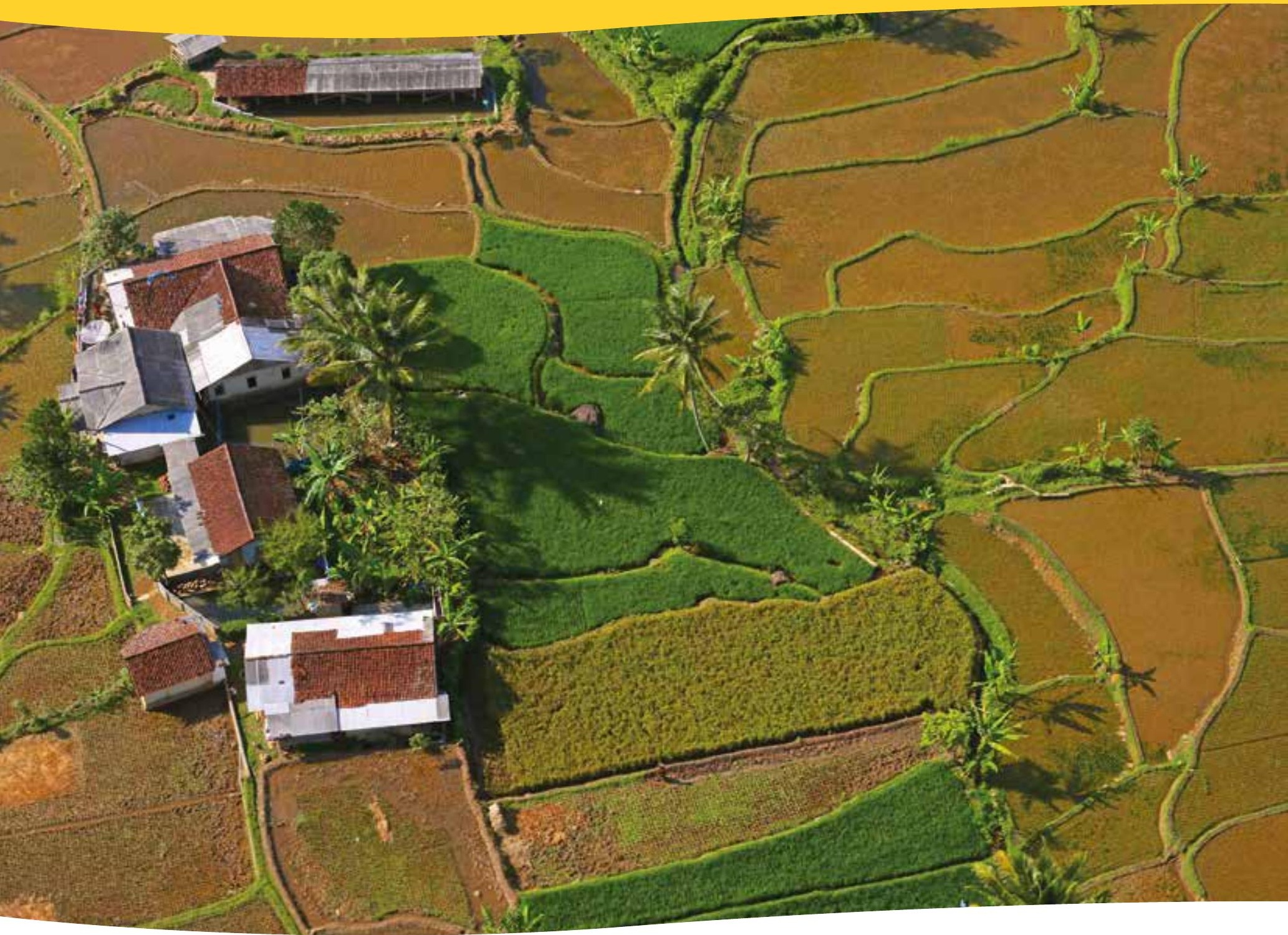

\title{
A review of the legal and policy framework for payments for ecosystem services (PES) in Thailand
}

Orapan Nabangchang 



\title{
A review of the legal and policy framework for payments for ecosystem services (PES) in Thailand
}

\author{
Orapan Nabangchang
}

School of Economics, Sukhothai Thammatirat Open University

Economy and Environment Program for Southeast Asia (EEPSEA) 
Working Paper 148

(c) 2014 Center for International Forestry Research

Content in this publication is licensed under a Creative Commons Attribution-NonCommercial-NoDerivs 3.0 Unported License http://creativecommons.org/licenses/by-nc-nd/3.0/

Orapan Nabangchang. 2014. A review of the legal and policy framework for payments for ecosystem services (PES) in Thailand. Working Paper 148. Bogor, Indonesia: CIFOR.

Photo by Kate Evans/CIFOR

Aerial view of the landscape around Halimun Salak National Park, West Java, Indonesia.

CIFOR

Jl. CIFOR, Situ Gede

Bogor Barat 16115

Indonesia

$\mathrm{T}+62(251) 8622-622$

$\mathrm{F}+62$ (251) 8622-100

E cifor@cgiar.org

cifor. org

We would like to thank all donors who supported this research through their contributions to the CGIAR Fund For a list of Fund donors please see: https://www.cgiarfund.org/FundDonors

Any views expressed in this publication are those of the authors. They do not necessarily represent the views of CIFOR, the editors, the authors' institutions, the financial sponsors or the reviewers. 


\section{Contents}

Abbreviations

1 Introduction 1

2 Experiences of PES in Thailand 1

2.1 Summary of EEPSEA study 1

2.2 PES projects at the design stage $\quad 2$

3 Legal framework for PES in Thailand $\quad 15$

3.1 Laws related to the areas that are the sources of ES 15

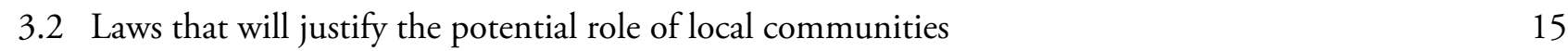

3.3 Is there a need for a PES law? $\quad 16$

3.4 Stakeholders 16

3.5 Concluding observations $r$

4 References $\quad 19$ 


\section{List of tables and maps}

\section{Tables}

1 Ongoing PES projects in Thailand 4

2 Key points in ARNWS PES pilot project design. 6

3 Key points in CBFCM pilot projects. 8

4 Key components of other ongoing PES projects in Thailand. 12

5 The progress of ongoing PES projects. 14

Map

1 Location of ongoing PES projects in Thailand. 5 


\section{Abbreviations}

ARNWS Ang Rue Nai Wildlife Sanctuary

ASEAN Association of Southeast Asian Nations

BEDO Biodiversity Economy Based Development Organization

CATSPA Catalysing Sustainability of Thailand's Protected Area System

CBFCM Community Based Forestry and Catchment Management

CPF Charoen Pokaphand Foods Co. Ltd.

CSR Corporate Social Responsibility

DMCR Department of Marine and Coastal Resources

DNP Department of National Parks, Wildlife and Plant Conservation

ES Ecosystem Services

ECOBEST Enhancing the Economics of Biodiversity and Ecosystems in Thailand/Southeast Asia

EEPSEA Economy and Environment Program for Southeast Asia

GEF Global Environmental Facility

GMS Greater Mekong Subregion

IUCN International Union for Conservation of Nature

MONRE Ministry of Natural Resources and Environment

NESDB National Economic and Social Development Board

NGO Non-Governmental Organization

ONEP Office of Natural Resources and Environmental Policy and Planning

PACT Protected Area Committee

PES Payments for Ecosystem Services

REO Regional Environment Offices

RTG Royal Thai Government

SAMPAN Strengthening Andaman Marine Protected Area Network

TEI Thailand Environmental Institute

UNDP United Nations Development Programme

WWF World Wide Fund for Nature 



\section{Introduction}

Thailand is somewhat lagging behind other countries in Southeast Asia in adopting the concept of payment for ecosystem services (PES) as an instrument for creating incentives for natural resources conservation in terms of demand and supply. There are a number of activities that involve payments of some kind for provision of activities or ecosystem services (ES) but are missing many elements that would qualify them as a PES project. There are also PES projects at the design stage. The purpose of this report is to review these experiences and to draw conclusions from them; and to highlight institutional and legal aspects of adopting PES as an instrument for natural resources conservation in Thailand.

This report is divided into four sections. Following this introduction, Section 2 will discuss the key findings of an exploratory study of PES or 'PES-like' projects and ongoing PES projects in Thailand. In Section 3, the legal framework for the adoption of the PES concept and its implementation is discussed, followed by an overview of the stakeholders involved and the roles they play in advocating or implementing PES projects. The last section is an overall assessment of PES experiences in Thailand, which examines the institutional structure and assesses how the concept of PES can contribute to poverty alleviation and support the creation of markets for biodiversity conservation.

\section{Experiences of PES in Thailand}

\subsection{Summary of EEPSEA study}

To gain some understanding of the PES experience in Southeast Asia, the Economy and Environment Program for Southeast Asia (EEPSEA) initiated a pilot research project to examine PES and PES-type projects in five countries: Cambodia, Indonesia, Malaysia, the Philippines and Thailand. The definition of PES used to identify and classify PES projects in Thailand is given by Wunder et al. (2008) as: "(1) a voluntary transaction where (2) a well-defined environmental service (ES) or a land use likely to secure that service (3) is being 'bought' by a minimum one service buyer (4) from a minimum one service provider (5) if and only if the service provider secures service provision (conditionality)." The initiatives undertaken satisfy some, but not all, of these criteria. The EEPSEA study refers to these as 'PES-like' projects (Jarungrattanapon et al. 2014). Of the eight cases identified, five were concerned with wildlife conservation and three cases were of forest conservation, mainly for carbon sequestration. The PES-like programs for wildlife conservation include: the Mai Khao Marine Turtle Conservation in Phuket province; the Adopting Elephant project; Gaur Conservation of the Khao Pang Ma Conservation Network; the Hornbill Adoption Program in the Budo-Sungai Padi National Park; and elephant conservation by the Elephant Conservation Network in Kanchanaburi. The PES-like schemes for forest conservation identified and discussed in this report include: a carbon sequestration project in Inpang Community Network in Northeast province (Carbon2Markets Program 2009); the Khlongrua Tree Bank in Chumphon province; and reforestation projects by private companies and state enterprise sectors including Toyota Motor Thailand Co. Ltd, The Coca-Cola Company (Thailand), The Petroleum Authority of Thailand (PTT) Public Company Ltd and the Electricity Generating Authority of Thailand (EGAT).

\subsubsection{Observations on the experience of implementing the concept of PES in Thailand}

First, most of the funding for natural resources conservation is primarily a corporate social responsibility (CSR) investment that results in ES. For marine turtles, local farmers run a program to protect nests from natural and human threats and keep quantifiable records of the numbers of eggs hatched. In the Guar Conservation Project, local villagers are engaged in a number of activities, i.e. reforestation, building check dams, forest fire prevention measures, restoring sources of water supply/mineral licks and managing grasslands as sources of food for wildlife. For hornbill conservation, the local villagers provide research support - they collect biological and ecological data on hornbills and monitor population levels in the area. What is common to all of these projects is that the ES aim to reduce the 'harm' done by local villagers who were formerly extracting these resources. By turning local farmers into service providers, the immediate threats are averted.

Second, while PES-like programs related to wildlife can generate voluntary contributions from private companies or from the general public, flows of contributions from these sources will be low for 
services of certain ecosystems such as watersheds, mangroves, wetlands, coral reefs, etc. These ecosystems have less 'warm glow' and the benefits of these ecosystems in providing 'life supporting' functions is more difficult for the general public to understand and appreciate. The main challenge is to demonstrate the direct and indirect benefits of ES so as to create real demand for their provision. To date, few attempts have been made to demonstrate the direct and indirect benefits from ES in Thailand.

Third, villagers involved in conservation activities are like waged workers and do not quite fit the definition of service providers. There are exceptions in the marine turtle and the hornbill conservation projects where financial incentives are provided. Villagers in the marine turtle conservation project are paid on the basis of output, i.e. they are paid USD 1.6 for every turtle egg saved. The Hornbill Adoption Program pays local villagers USD 5 per day to look after the nests but it is not clear how many nests each villager is looking after or what incentives are provided to ensure their continued performance.

Fourth, Inpaeng community project has all the components of a PES project, i.e. there are service providers involved in reforestation and sellers, and there are baselines from which to measure the 'additionality'. Others are more like CSR projects, which involve undertaking activities, in this case reforestation. What is interesting about this project is that the Inpaeng network has been in existence since 1987 and has been cited as a case of success. Over the years, many study tour visits have been organized so that other local communities, government agencies and universities can come and learn from their experiences. Yet, despite the fact that many other local communities have been given the incentives engage in similar activities, the replication of Inpaeng elsewhere has been limited to date. Given that some of the ongoing PES projects discussed in the next section have identified carbon sequestration functions among the ES, the experiences of Inpaeng community will be all the more valuable.

Fifth, based on the information available, there are two types of intermediaries: those with vested interests and those who are service providers.

1. Intermediaries with vested interests. The intermediaries in all cases have vested interests in mobilizing funds for conservation, i.e. the increased publicity or improved image of the private sector involved as an intermediary in return for increased funds to reduce the threats and to increase the welfare of endangered species. For marine turtle conservation, the role of JW Merriot Phuket is both as an intermediary and a buyer, since the business also directly benefits from the environmental services. The Khao Pang Ma conservation network fits the definition of an intermediary somewhat better because it acts as a link between buyers and sellers.

2. Intermediaries who are service providers. A distinction must be made between the agencies that are engaged in conservation work as part of their mandate and are using their normal budgetary allocation to do so. The Royal Thai Navy and Phuket Marine Biological Center, for example, have budgetary resources for marine turtle conservation in Mai Khao beach, Phuket province. What these agencies do cannot strictly be defined as providing ES, because there is no element of 'transactions' being made. Moreover, as conservation measures were undertaken are part of their mandate, there is in effect no additionality. Nevertheless, these agencies can still be considered as intermediaries if some of the budgetary resources allocated are used to engage local people in conservation efforts, which they would not otherwise have done. The same applies to the two elephant conservation projects: the Asian Elephant Foundation of Thailand, the Elephant Conservation Network, and the Department of National Parks, Wildlife and Plant Conservation (DNP).

Lastly, there is potential to develop existing PESlike projects into PES projects, which would sustain conservation efforts. There are no objections to CSR investments, but since investors do not benefit from the ES that they are paying for, donations have tended to be a one-time investment with no guarantee of continuity in funding. To develop the existing PES-like projects into PES projects, there is a need to revisit the actions to provide $\mathrm{ES}$, particularly in terms of the costs to provide the services and the transaction costs. Other elements that need to be expanded include establishing baselines to measure 'additionality' and identifying the beneficiaries of ES, how they benefit and how to measure the benefits.

\subsection{PES projects at the design stage}

Although Thailand does not have ongoing PES projects, there are 16 projects altogether that are at the design stage or at the initial stages of implementation. 
They will be the first PES projects to be implemented in Thailand. These include four pilot projects under the Community Based Forestry and Catchment Management (CBFCM) project funded by the United Nations Development Program-Global Environment Facility (UNDP-GEF); five projects under the Catalysing Sustainability of Thailand's Protected Area System (CATSPA), which receives support from UNDP-GEF; five PES projects which have been initiated by the Biodiversity-EconomyBased Development Organization (BEDO) and two projects initiated by the Enhancing the Economics of Biodiversity and Ecosystems in Thailand/Southeast Asia (ECOBEST). These projects, the main ES, the project proponent and sources of funding are listed in Table 1 and the location of these sites are shown on Map 1.

The author has been involved in the design of Ang Rue Nai Wildlife Sanctuary (ARNWS) PES pilot project and four PES sites under CBFCM, and these projects are discussed in detail in Sections 2.2.1 and 2.2.2.

The information on other PES projects presented in Table 4 is based on interviews with those involved in the project design. The progress of each of these projects is assessed in terms of their progress in the 20 steps of PES project design and implementation ${ }^{1}$.

\subsubsection{Ang Rue Nai Wildlife Sanctuary (ARNWS)}

One of the pioneering studies in Thailand was initiated by BEDO. Using ARNWS as the pilot study site, the aim of the project was to explore the potential use of the PES concept to promote sustainable management of natural resources and contribute to economic development at the community level. ARNWS is a lowland rainforest and is part of the Rabom Si Yad National Forest Reserve located in Chachoengsao province. The sanctuary borders four provinces: Sra Kaew, Prachinburi, Chantaburi and Rayong. The sanctuary's total area is $674,352 \mathrm{rai}^{2}$ or 1079 $\mathrm{km}^{2}$. ARNWS is one of seven protected areas that have more than 100 elephants. ARNWS elephant population was 136-200 in 2006 and increased to 217 elephants in 2007.

ARNWS is the watershed of the Bang Pakong River and Prasae River, which are major sources of surface water supply for residential areas, industries and agricultural production in the downstream

Scheufele G, Bennette J, Kragy M and Renton M. 2014. rai is Thai unit of area measurement 1 hectare $=6.25$ rai area. Over the years, as the ecosystems were degraded many of the key species in the area, such as freshwater crocodiles and tigers, have become extinct. In the absence of natural predators, the population of elephants has been increasing by $9.83 \%$ per annum, and population growth rate is said to be higher than in other habitats (Wanghongsa et al. 2006). In 2007, the estimated elephant population in ARNWS was 217 and the crude density was 0.2 elephant $/ \mathrm{km}^{2}$. It has been estimated that only $36.63 \%$ of the sanctuary is suitable elephant habitat. Thus, because of the shortage of food and water, elephants often leave the sanctuary, making ARNWS an area with a high level of human-elephant conflict (HEC). Over the years, there have been some efforts to restore sections of the degraded ecosystem by closing roads during certain times of the day, increasing food supplies, mineral licks and water sources within the sanctuary, and digging canals. However, the scale of these activities has been limited by the availability of financial resources. The efforts were piecemeal and fell short of the scale of measures required to sustain any the positive impacts. This was why the idea of PES was considered as a possible solution.

Ecosystem services. Although the situation in ARNWS does not strictly comply with the typical PES setting, i.e. with clearly defined upstream service providers and downstream service buyers, the sanctuary's ecosystem is clearly degraded. Rehabilitation measures would ensure a sustainable flow of services (particularly water) where there are already existing beneficiaries and potential buyers. In addition to the potential use values that can be generated from ecotourism activities, there are also the intangible benefits such as the indirect use value from the rehabilitation of the ecosystem as well as the non-use value of wild elephants, which has symbolic, historical and cultural significance in Thai society. Through consultation with wildlife experts and the staff of ARNWS, the following activities have been proposed:

- Make water supplies available within the sanctuary to reduce the need for elephants to leave the sanctuary to search for water.

- Mineral licks.

- Plant food for elephants.

- Fence part of the sanctuary.

- Reforest and a forest.

Measuring additionality. Since the measure of success of a PES project is not about what measures are undertaken but about the outcomes measured 
Table 1. Ongoing PES projects in Thailand.

\begin{tabular}{|c|c|c|c|c|}
\hline Area & Legal concerns & Ecosystem services & $\begin{array}{l}\text { Project } \\
\text { proponent }\end{array}$ & Initial source of funding \\
\hline \multicolumn{5}{|c|}{ Catalysing Sustainability of Thailand's Protected Area System } \\
\hline $\begin{array}{l}\text { Watershed forest } \\
\text { about } 300,000 \text { raiin } \\
3 \text { villages }\end{array}$ & $\begin{array}{l}\text { Site located in protected area } \\
\text { (Doi Inthanon National Park) }\end{array}$ & Watershed & DNP & UNDP-GEF \\
\hline \multicolumn{5}{|l|}{$\begin{array}{l}\text { (Mae Ga-Luang,Pa } \\
\text { Morn, Khun Klang) }\end{array}$} \\
\hline \multirow[t]{2}{*}{ Nakhon Sawan } & $\begin{array}{l}\text { Site located in Klong Larn } \\
\text { National Park and Huey Kha } \\
\text { Kaeng Wildlife Sanctuary }\end{array}$ & Wildlife habitat & DNP & UNDP-GEF \\
\hline & Mae Wong Wildlife Sanctuary & $\begin{array}{l}\text { Wildlife habitat } \\
\text { and watershed }\end{array}$ & DNP & UNDP-GEF \\
\hline $\begin{array}{l}\text { Satun Province: } \\
\text { Southern Region }\end{array}$ & $\begin{array}{l}\text { Tarutao Marine Protected } \\
\text { Area }\end{array}$ & $\begin{array}{l}\text { Ecotourism and } \\
\text { recreational value }\end{array}$ & DNP & UNDP-GEF \\
\hline $\begin{array}{l}\text { Eastern Forest } \\
\text { Complex }\end{array}$ & Wildlife sanctuary & $\begin{array}{l}\text { Wildlife habitat and } \\
\text { watershed }\end{array}$ & DNP & UNDP-GEF \\
\hline \multicolumn{5}{|c|}{ Community Forestry Based Catchment Management } \\
\hline \multirow{2}{*}{$\begin{array}{l}\text { Mae Sa Watershed, } \\
\text { Chiang Mai }\end{array}$} & Protected area & Watershed & REO & UNDP-GEF \\
\hline & & Recreation & & \\
\hline $\begin{array}{l}\text { Lam Sebai } \\
\text { Community Forest, } \\
\text { Northeast Thailand }\end{array}$ & Community forest & $\begin{array}{l}\text { Water supply and } \\
\text { water purification } \\
\text { functions }\end{array}$ & REO & UNDP-GEF \\
\hline \multirow{2}{*}{$\begin{array}{l}\text { Tha Chin River } \\
\text { outlet, Central } \\
\text { Thailand }\end{array}$} & Private land & $\begin{array}{l}\text { Water quality } \\
\text { improvement; }\end{array}$ & REO & UNDP-GEF \\
\hline & & $\begin{array}{l}\text { Mangroves' coastal } \\
\text { protection function; } \\
\text { fish spawning ground } \\
\text { and habitat }\end{array}$ & & \\
\hline $\begin{array}{l}\text { Phangan Island, } \\
\text { Southern Thailand }\end{array}$ & $\begin{array}{l}\text { Site located in a marine } \\
\text { national park }\end{array}$ & $\begin{array}{l}\text { Mangroves; } \\
\text { coral reefs }\end{array}$ & REO & UNDP-GEF \\
\hline $\begin{array}{l}\text { Ang Rue Nai } \\
\text { Wildlife Sanctuary } \\
\text { (ARNWS) }\end{array}$ & $\begin{array}{l}\text { Site located in a wildlife } \\
\text { sanctuary - restricted access }\end{array}$ & Wildlife habitat & BEDO & Not yet identified \\
\hline $\begin{array}{l}\text { Klong prasom: } \\
\text { Krabi }\end{array}$ & Property rights are unclear & Mangroves & BEDO & $\begin{array}{l}\text { Local villagers who } \\
\text { benefit }\end{array}$ \\
\hline $\begin{array}{l}\text { Thung Jor, Chiang } \\
\text { Mai }\end{array}$ & $\begin{array}{l}\text { Site located in a wildlife } \\
\text { sanctuary - restricted access }\end{array}$ & Watershed & BEDO & Provincial Water Work \\
\hline $\begin{array}{l}\text { Pathiu district, } \\
\text { Chumphon }\end{array}$ & Property rights are unclear & Mangroves & BEDO & CPF a subsidiary of $\mathrm{CP}^{*}$ \\
\hline $\begin{array}{l}\text { Santisuk district, } \\
\text { Nan Province }\end{array}$ & Property rights are unclear & & BEDO & CPF a subsidiary of CP \\
\hline $\begin{array}{l}\text { Dong Phayayen- } \\
\text { Khao Yai Complex }\end{array}$ & $\begin{array}{l}\text { Site is located in a protected } \\
\text { area - restricted access }\end{array}$ & Watershed & ECOBEST & $\begin{array}{l}\text { EU, German } \\
\text { Government, RTG, } \\
\text { Helmholtz university }\end{array}$ \\
\hline $\begin{array}{l}\text { Klong Nadi, } \\
\text { Nakhon Sri } \\
\text { Thammarat }\end{array}$ & Property rights are unclear & Watershed & ECOBEST & $\begin{array}{l}\text { EU, German } \\
\text { Government, RTG, } \\
\text { Helmholtz university }\end{array}$ \\
\hline
\end{tabular}

* Charoen Pokphand Group (CP) is Thailand's largest and influential agribusiness which also operate in China as well as other countries in Southeast Asia 


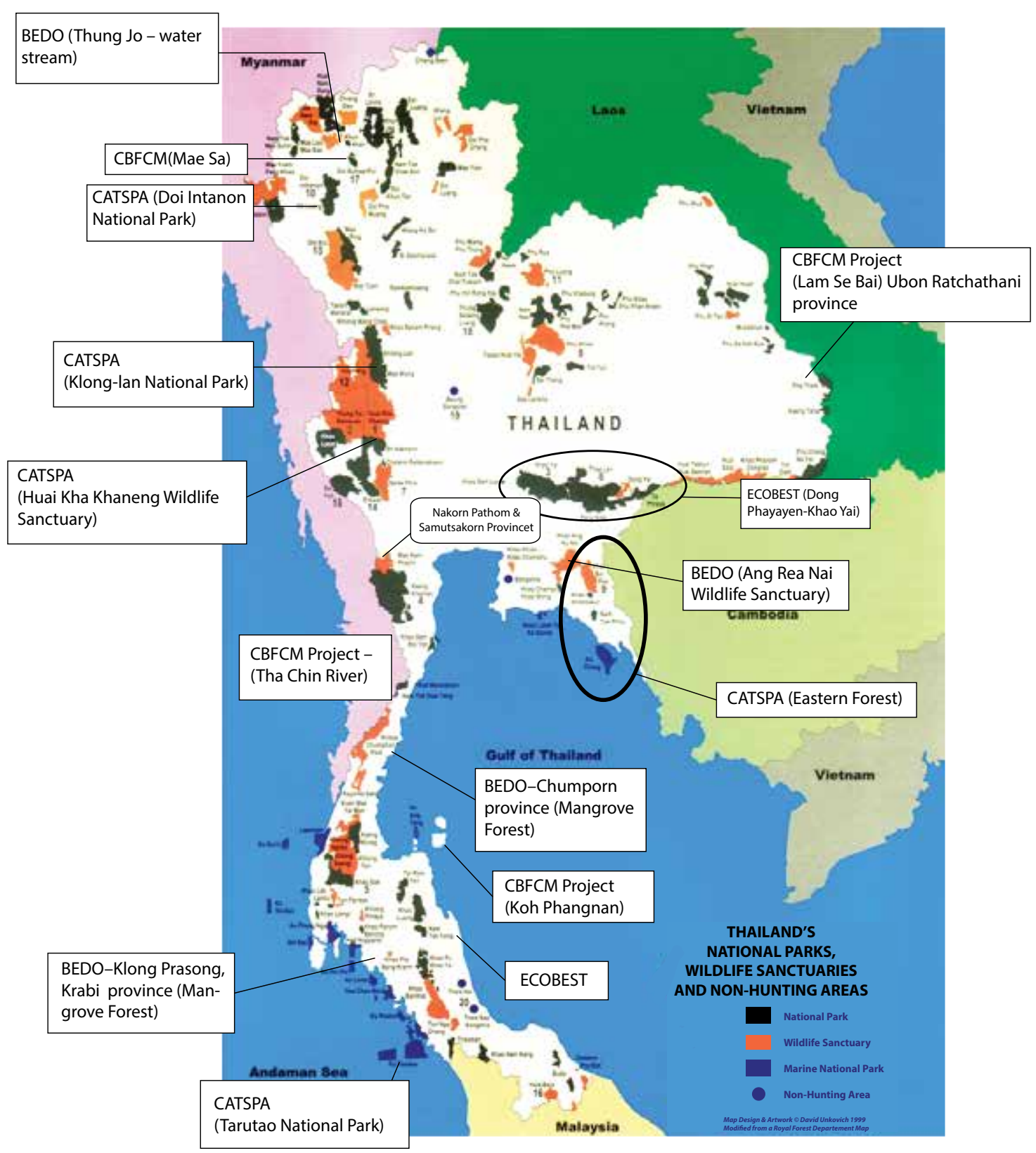

Map 1. Location of ongoing PES projects in Thailand.

in terms of an improved ecosystem, expected outputs are specified for each of the activities proposed, as well as indicators of how they can be measured and how they can be monitored. For example, cameras will be installed at the locations of the water sources, mineral licks and food patches, and through the use of GPS systems, the villagers (service providers) will collect data on the number, timing and type of wildlife that benefit from these resources. This will provide concrete evidence of the improvement in the ecosystems and will reduce the incidence of crop raiding by elephants, resulting in less damage to crops and property and reduction in the levels of fear of raids by elephants among local people.
Implementation costs. The cost of launching this pilot PES project is divided into two categories: (i) investment costs for the various proposed activities and (ii) costs for monitoring and evaluation.

Service providers. The service providers are local people from six villages that border the sanctuary. The majority of the 2,247 households are affected by elephants raiding crops. For these households the damage costs from crops grown (such as cassava, rice and rubber) property damage and medical expenses related to elephant crop-raiding incidences was equivalent to between 14 and $34 \%$ of their average household income. When asked if they would be interested in participating in activities to restore the 
ecosystem within the sanctuary, more than $90 \%$ of the 200 villagers interviewed said that they would be willing to volunteer their labor even if there was no payment. In many respects, this response was to be expected. These villagers were already spending money to protect their crops and property. Any measures that would lead to a reduction in the incidence of crop raiding would reduce their current expenses. Technically speaking, the villagers are beneficiaries as well as service providers; the latter capacity is justified on the grounds that there are external positive benefits to users and the general public from the direct and indirect benefits of restored ES as well as the non-use values of the biodiversity resources in the sanctuary where the elephant is an umbrella species.

Service buyers. Perhaps the most challenging part of launching the PES project, particularly for a site such as ARNWS, is the identification of buyers.

Apart from the service providers who directly benefit from the measures that will be undertaken, the beneficiaries of the ES are essentially those who rely on the water supply from the Bangpakong River and Prasae River. The single largest user is the East Water Company, a private business that has shown considerable interest in becoming a contributor. At

Table 2. Key points in ARNWS PES pilot project design.

\begin{tabular}{|c|c|}
\hline & Ang Rue Nai Wildlife Sanctuary \\
\hline \multirow[t]{2}{*}{ Ecosystems services } & Wildlife habitat \\
\hline & Watersheds \\
\hline \multirow[t]{6}{*}{ Activities to be undertaken by service providers } & $\begin{array}{l}\text { Making water supplies available within the sanctuary to reduce } \\
\text { the need for elephants to leave the sanctuary to search for water. }\end{array}$ \\
\hline & Creating mineral licks. \\
\hline & $\begin{array}{l}\text { Increasing the grassland area within the sanctuary. A substantial } \\
\text { part of the sanctuary faces problem of rapid expansion of invasive } \\
\text { species. These would need to be weeded out to provide more } \\
\text { open space and sunlight. }\end{array}$ \\
\hline & Planting food for elephants. \\
\hline & Fencing part of the sanctuary. \\
\hline & Reforestation and afforestation. \\
\hline \multirow[t]{4}{*}{ Indicators of 'additionality' } & Animals visiting mineral salt licks \\
\hline & Animals visiting the water sources inside the sanctuary \\
\hline & Reduced incidences of wild elephants leaving the park \\
\hline & Reduced damage costs \\
\hline Service providers & $\begin{array}{l}\text { Villagers with properties located on the boundary of the ARN } \\
\text { wildlife sanctuary }\end{array}$ \\
\hline \multirow[t]{3}{*}{ Economic analysis } & $\begin{array}{l}\text { No estimates of ES benefits available but the following estimates } \\
\text { have been made: }\end{array}$ \\
\hline & - benefits in terms of avoided costs \\
\hline & - cost-effectiveness analysis of different management options. \\
\hline \multirow[t]{3}{*}{ Institutional issues } & There is no host agency. \\
\hline & $\begin{array}{l}\text { Apart from signing a memorandum of understanding with the DNP } \\
\text { agreeing in principle collaboration between the two organizations } \\
\text { in launching this PES project, BEDO's role has been limited to } \\
\text { providing financial support for the design of the project. }\end{array}$ \\
\hline & $\begin{array}{l}\text { There is possibility that ARNWS PES project will be considered as } \\
\text { part of the Eastern Forest Complex site under the CATSPA project }\end{array}$ \\
\hline \multirow[t]{3}{*}{ Legal issues } & $\begin{array}{l}\text { Site is located within the watershed where the level of restriction } \\
\text { is highest. }\end{array}$ \\
\hline & Villagers do not have property rights \\
\hline & $\begin{array}{l}\text { Some kind of agreement will have to be made with the DNP to } \\
\text { allow the villagers to enter the watershed. }\end{array}$ \\
\hline
\end{tabular}


a meeting organized to discuss the objectives of the ARNWS PES pilot project, East Water pointed out that they need to know the ongoing development projects being funded by government agencies and businesses as part of their CSR investments. Knowing what, where and at what stage these projects are would help them in their planning processes, in identifying overlaps of investments and in channeling resources to where there are gaps. But having a single buyer may not be sufficient for the initial investment or the costs of recurring activities. It is essential to involve other potential contributors. During the initial period, there was an expectation that it would be possible to mobilize contributions from the private sector. This is because private-sector companies spend considerable sums each year on public relations and CSR investments. The ARNWS PES pilot project already offered an opportunity for companies to do 'good', improve their CSR image and earn good publicity.

\subsubsection{Community Based Forestry and Catchment Management Project (CBFCM)}

The objective of the CBFCM project is to create an enabling policy and institutional environment for scaling-up integrated CBFCM. This will be achieved through innovative financing mechanisms, through pilot testing of defined payment for environmental services (PES) to create incentives for local communities to conserve biodiversity and to reduce greenhouse gas emission from land uses. This will involve harmonizing policies, plans and legal instruments, and supporting the establishment of a multisectoral mechanism for CBFCM. A key objective of CBFCM is to strengthen national capacities to promote PES as a way of creating community incentives for effective forest and catchment management. In addition, the project will strengthen the capacities of local authorities, landholders and the private sector. The goal, objectives and outcomes were intended to support the goals of the United Nations Partnership Framework with the Kingdom of Thailand 2007-2011 (UNPAF) by promoting capacity building at local levels for environmental management, sustainable resource use and cleaner energy. The CBFCM project fulfills part of UNDP's Country Programme Action Plan (2007-2011) for Thailand under the Energy and Environment Outcomes, which include: (i) efficient community-based natural resources and environmental management in selected ecosystems; (ii) increased capacity of national agencies to set policy priorities and remove barriers to pursuing sustainable management of biodiversity, renewable energy and water resources; and (iii) promoting community-based knowledge management by supporting the formation of community networks and promoting evidence-based policymaking at all levels.

The launch of this project was driven by the country's needs and was identified as a priority project by the Ministry of Natural Resources and Environment (MONRE). It satisfies Thailand's GEF strategy of providing support to the implementation of the 10th National Economic and Social Development Plan (NESDB 2007-2011) and is consistent with the 11th National Economic and Social Development Plan (2012-2016) which emphasises: (i) the importance of sustainable management of natural resources and environment towards sustainability; (ii) restoring and securing natural resource and environment bases; (iii) enhancing adaptive capacity to achieve a climateresilient society; and (iv) enhancing good governance in natural resource management. The project is anchored on Target 9 of Millennium Development Goal 7, which aims to integrate sustainable development into country policies and programs and to reverse the loss of environmental resources. The relationship between natural resource and environmental management and greenhouse gases can be synthesized from the National Strategy on Management of Climate Change and the 4-year operational plan of the Ministry of Natural Resources and Environment.

Under the CBFCM project, four sites were identified to pilot PES: Mae Sa Catchment (north), Tha Chin Catchment (central), Lam Sebai Catchment (northeast), and Pa-Ngan Catchment (south). The core agency is four regional environment offices (REOs) who are expected to collaborate closely with the Office of Natural Resources and Environmental Policy and Planning (ONEP) and the DNP to ensure that there is effective policy feedback and knowledge sharing. Following GEF approval of financial support, UNDP commissioned a study to revisit the sites identified. The 6-month study was expected to produce: a preliminary analysis of the ES, the activities to undertake, the service providers and the potential service buyers. More importantly, the expected output was to assess and identify the gaps in information required for the design of a PES project for these sites. Table 3 summarizes the outputs of those 6 months in 10 areas: (i) target area and justifications; (ii) ES; (iii) activities to be undertaken; (iv) indicators of change; (v) service providers; (vi) beneficiaries of ES or the potential buyers; (vii) assessment of information gaps; (viii) economic analysis available or to be undertaken; (ix) capacity-building needs; and (x) legal and institutional issues. The study was completed in September 2013. 


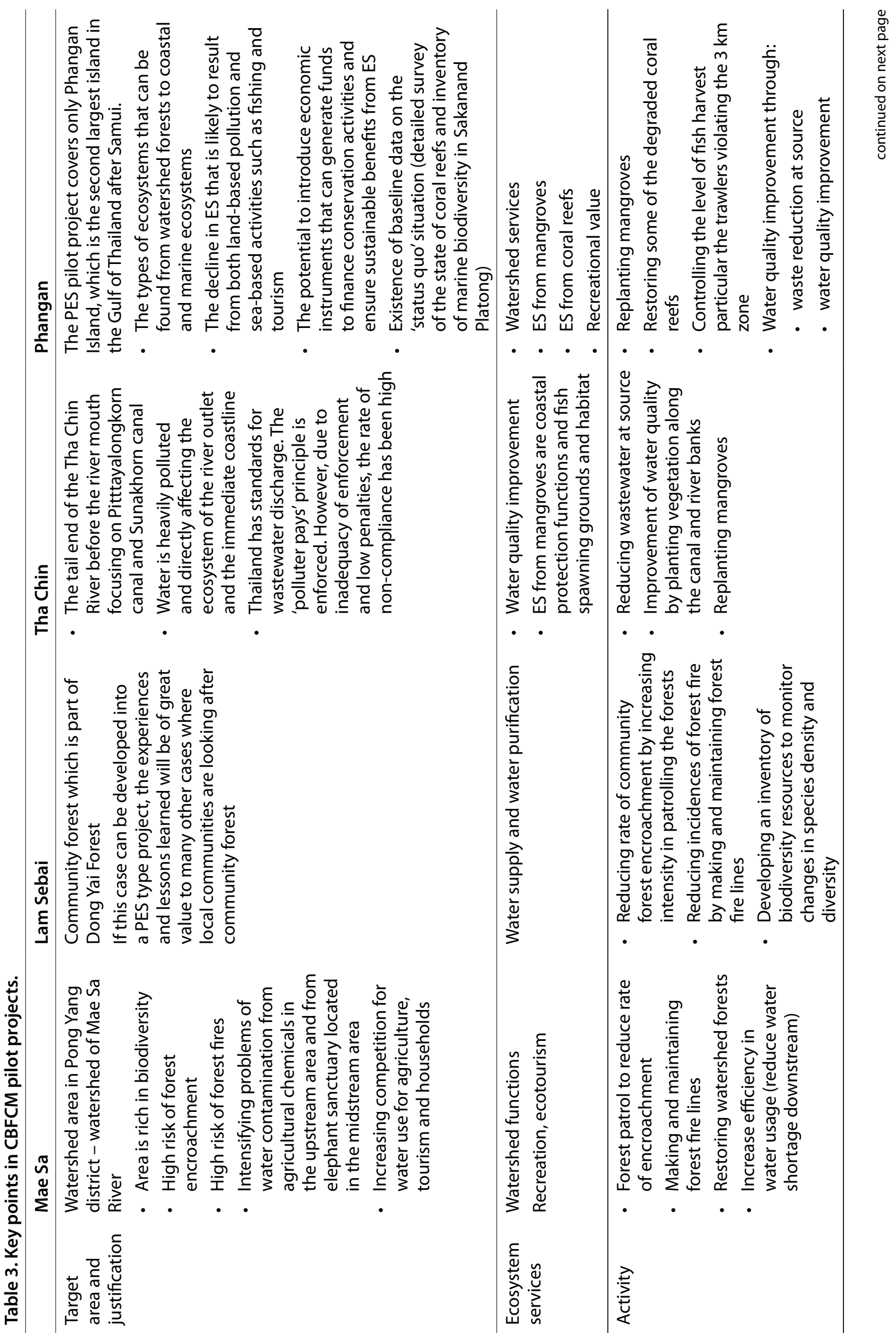




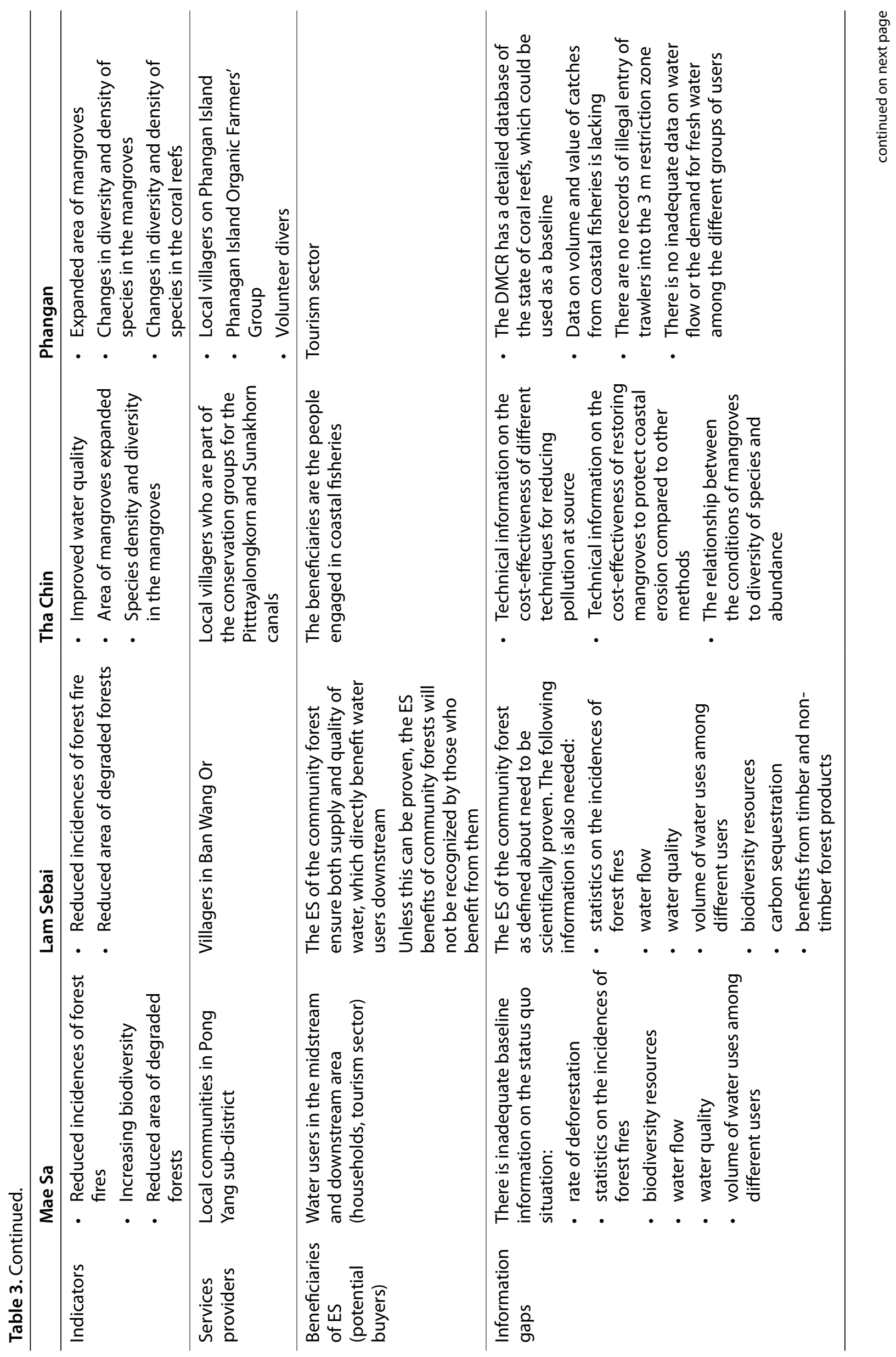




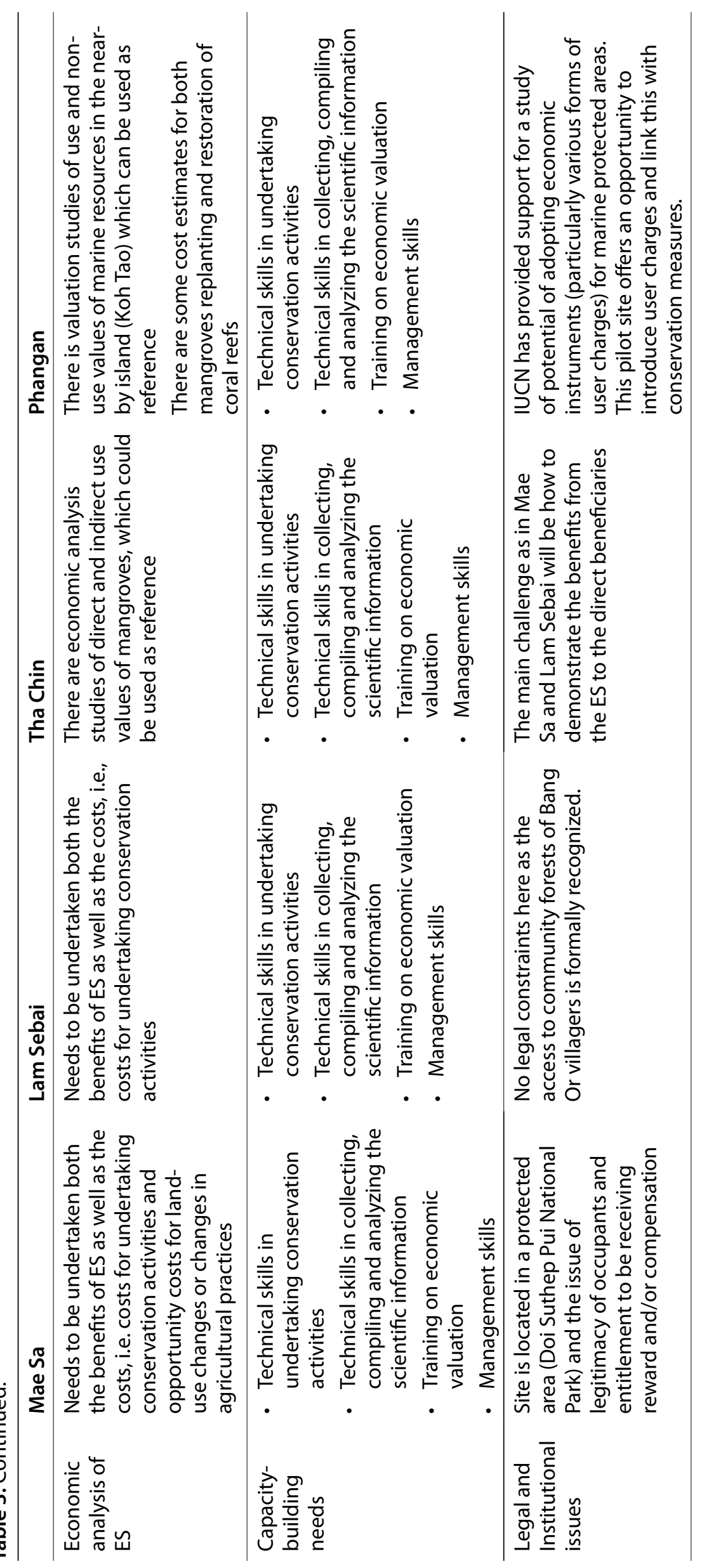




\subsubsection{Other ongoing PES projects}

The information on other ongoing initiatives is based on interviews with key persons involved in those projects. The information for each project is summarized in terms of: (i) the ES of the chosen sites; (ii) the proposed activities; (iii) the indicators for measuring the additionality resulting from the activities being undertaken; (iv) the service providers; (v) the beneficiaries and potential buyers; (vi) the economic analysis that has been undertaken; and (vii) some observations about the institutional aspects (Table 4).

\subsubsection{PES in Thailand: Current situation}

The 20 steps required to design and implement PES schemes that are currently being used for design of the PES project in Lao PDR are being used as a frame of analysis to assess ongoing PES projects in Thailand (Scheufele et al. 2014). The results presented in Table 5 show that all projects have started to implement steps $1-4$. Some studies have provided more information than others, and some services providers have begun conservation work, even in the absence of details of components considered to be key to PES projects.

The selection of geographical areas was based on a number of considerations, such as: regional distribution; representatives of different ecosystems; the importance of the sites in terms of ecological importance, vulnerability and pressures on the ecosystems, plant species and wildlife. There is a wide geographical spread of ongoing PES projects.

Once Step 1, which is selecting and defining the geographical area has been taken, the challenge of Step 2 is to reach an agreement on the ecosystems under consideration and measures that must be undertaken to restore, protect or conserve natural resources. In most cases, apart from observations from stakeholders, there is no baseline information available to represent the status quo situation. There have been disagreements between local communities and the so-called 'technical experts' over the changes in environmental quality, measures to be undertaken and the flows of ES. For the CBFCM sites, a preliminary baseline review of what information is available and what is missing is required. Technical and financial resources should be allocated for this purpose.

Step 3: Identifying the beneficiaries of ES. The main challenge of this step was not in identifying who the beneficiaries are but to encourage them to recognize the benefits they receive. Many private-sector businesses that benefit from ES (e.g. those relying on watershed functions) either argue that they have alternative sources of water supply or that water quality is not an issue. A substantial effort must be made to clarify the beneficiaries of ES and the economic value of the benefits. This step has been bypassed as many PES initiatives have focused on tapping CSR investments. This means that sources of payment for ES for many PES projects discussed here do not come from those who benefit from the ES.

Step 4: Identifying potential ES supply. In all of the projects listed, the service providers identified are mainly local people who live within or near the sites. As most of these will be villagers who are already either living in or benefiting from resources in the protected areas, the main concern here is to justify whether they can be service providers with entitlements to receive rewards or compensation.

Step 5: Defining the type and degree of agent intervention. This refers to the agent(s) who mediate between buyers and facilitators in facilitating the transaction. For projects such as CATPSA and CBFCM, this intermediary role is usually an input provided by the project. In principle, intermediaries should be provided by the host agency, i.e. DNP for CATSPA sites and the REOs for CBFCM sites. However, unless the host agencies have a greater sense of project ownership and stop seeing this role as an add-on to the routine project responsibilities, PES activities are unlikely to be sustained beyond the time frame of internationally funded projects. With the exception of the ARNWS project, BEDO has taken up the role of intermediary, negotiating with the Provincial Water Works who is the direct beneficiary of water supply in Thung Jor (Chiang Mai); and with CPF, a private agri-business company, for investment in CSR funds to support local villagers to replant forests in Nan and mangroves in Chumpon. For ARNWS, some efforts were made to involve East Water Company, a direct beneficiary of water supply from Rayong and Prasae River. BEDO had tried to negotiate for CSR funds from PPT Public Co. Ltd. and SCG Co. Ltd., but efforts had proven unsuccessful to date.

Beyond Step 5, there is really no firsthand experience in Thailand. Step 6: Selecting buyers depends on the outcome of clarification about who is benefiting from $\mathrm{ES}$, in what way, and by how much (Step 3).

For Step 7: Securing funds for ES supplies pilot projects under CATSPA and CBFCM would have the benefit of seed funds from the project to launch the process. Indeed, for ARNWS, it was planned 


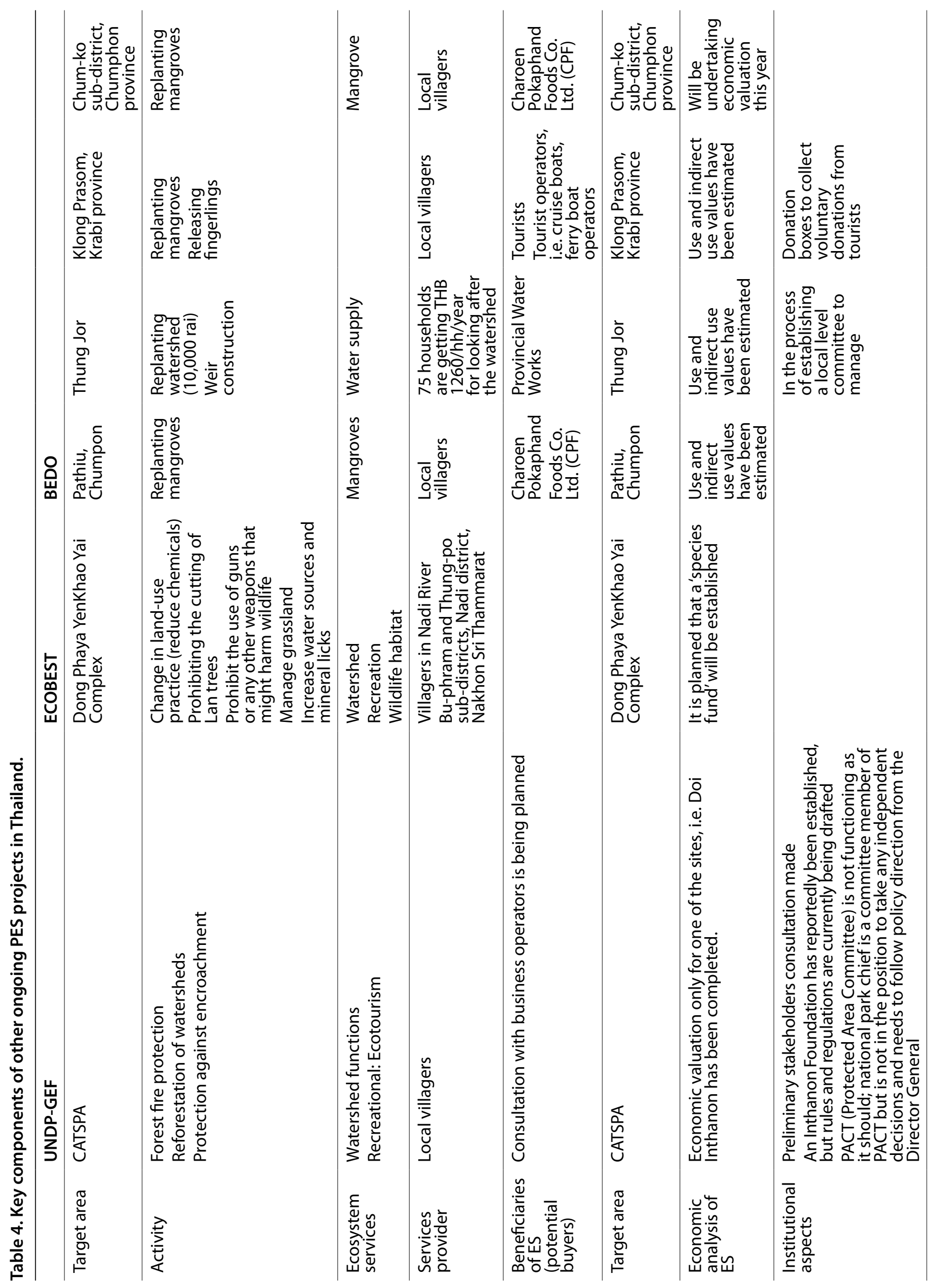


that seed funds from the direct beneficiary (East Water Co. Ltd. ) and CSR investments would be sufficient to launch the process and that once launched, the 'additionality' from provision of ES would be the assurance factor for sustainable flow of funds. But this never happened and when BEDO (the organization that initiated this project) did not pursue the matter any further, the ARNWS PES pilot project stopped at the design stage. All PES projects relying on CSR funds face the same risks. The period where CSR funds of project funds are available should be considered as an interim phase during which negotiations with the beneficiaries of ES can take place.

Step 8: Determining the types of returns to ES suppliers. For those projects already launched, the only type of payment is cash. Many PES sites are located in protected areas where land occupants have no formal or legal security of tenure. While providing security of tenure might be one type of 'return', any such proposal would conjure up debate over legitimacy and entitlement of service providers in protected areas to rewards or compensation.

Step 9: Biophysical modeling. This stage is relatively straightforward. Implementing agencies such as DNP, REO and DMCR all have in-house technical experts to undertake the work required. There are stocks of information on the biophysical data within the organizations that can already provide some of the baseline information needed.

Step 10: Estimating the marginal benefits is one of the three steps that require the inputs of environmental economists, the other two are: Step 11: Estimating the individual costs of ES supplies and Step 13: Selecting ES suppliers. Estimates have made of the household damage caused by wild elephants for ARNWS which could be used as a proxy of benefits if this is to be interpreted as avoided costs (Nabangchang and Srisawalak 2011). For the Inthanon site, one of the pilot sites under CATSPA, a study has been undertaken to estimate use and non-use values of natural resources in Doi Inthanon National Park, which is being used as a reference for the economic value of the benefits (Nabangchang 2009). Estimates of economic value in terms of direct use and indirect use have been completed for ES in mangroves in Krabi and Chumphon (BEDO) and for watershed services in Thung Jor, Chiangmai site. Economic valuation is easy to do badly if there is inadequate attention given to theoretical constructs behind each of the valuation tools. Researchers can easily get caught in the numerous pitfalls during the design stage, the execution of the surveys and the analysis of the results. The issue of how to communicate the results to the beneficiaries of ES and how to create 'recognition' of the benefits is also important. The importance of communicating the results of valuation studies undertaken could have been downplayed because of the easy availability of seed money from projects or from firms who want to invest in CSR activities.

Steps 11 to 20 as reflected in Table 5 are unknown for PES projects in Thailand. With the exception of some recommendations on the importance of monitoring and what should be monitored, no ongoing PES projects have yet reached these stages. 


\begin{tabular}{|c|c|c|c|c|c|c|c|c|c|c|c|c|c|c|c|c|c|c|c|c|c|}
\hline 요 & $\begin{array}{l}\text { Assessing the PES } \\
\text { scheme }\end{array}$ & & & & & & & & & & & & & & & & & & & & \\
\hline$\stackrel{a}{-}$ & Contracting the ES & & & & & & & & & & & & & & & & & & & & \\
\hline$\stackrel{\infty}{-}$ & $\begin{array}{l}\text { Establishing a penalty } \\
\text { non-compliance }\end{array}$ & & & & & & & & & & & & & & & & & & & & \\
\hline 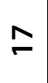 & $\begin{array}{l}\text { Establishing a } \\
\text { monitoring }\end{array}$ & & & & & & & & & & & & & & & & & & & & \\
\hline$\stackrel{0}{-}$ & $\begin{array}{l}\text { Determining the } \\
\text { supplier measure }\end{array}$ & & & & & & & & & & & & & & & & & & & & \\
\hline$\stackrel{n}{\sim}$ & $\begin{array}{l}\text { Establishing the } \\
\text { payment transfer } \\
\text { mechanism }\end{array}$ & & & & & & & & & & & & & & & & & & & & \\
\hline \pm & $\begin{array}{l}\text { Determining the } \\
\text { payments from buyer }\end{array}$ & & & & & & & & & & & & & & & & & & & & \\
\hline$\underline{m}$ & $\begin{array}{l}\text { Selecting the ES } \\
\text { suppliers }\end{array}$ & & & & & & & & & & & & & & & & & & & & \\
\hline$\simeq$ & $\begin{array}{l}\text { Developing the } \\
\text { payment system }\end{array}$ & & & & & & & & & & & & & & & & & & & & \\
\hline$=$ & $\begin{array}{l}\text { Estimating individual } \\
\text { marginal cost }\end{array}$ & & & & & & & & & & & & & & & & & & & & \\
\hline 으 & $\begin{array}{l}\text { Estimating marginal } \\
\text { benefits of supply }\end{array}$ & & & & & & & & & & & & & & & & & & & & \\
\hline$a$ & Bio-physical modeling & & & & & & & & & & & & & & & & & & & & \\
\hline$\infty$ & $\begin{array}{l}\text { Determining the } \\
\text { types of returns to ES } \\
\text { suppliers }\end{array}$ & & & & & & & & & & & & & & & & & & & & \\
\hline$\wedge$ & $\begin{array}{l}\text { Securing funds to pay } \\
\text { for the ES }\end{array}$ & & & & & & & & & & & & & & & & & & & & \\
\hline$\bullet$ & Selecting the ES buyers & & & & & & & & & & & & & & & & & & & & \\
\hline in & $\begin{array}{l}\text { Defining the type and } \\
\text { degree of agent }\end{array}$ & & & & & & & & & & & & & & & & & & & & \\
\hline + & $\begin{array}{l}\text { Identifying potential ES } \\
\text { supply }\end{array}$ & & & & & & & & & & & & & & & & & & & & \\
\hline$m$ & $\begin{array}{l}\text { Identifying the sources } \\
\text { of ES demand }\end{array}$ & & & & & & & & & & & & & & & & & & & & \\
\hline N & $\begin{array}{l}\text { Cataloging the ES to be } \\
\text { supplied }\end{array}$ & & & & & & & & & & & & & & & & & & & & \\
\hline- & $\begin{array}{l}\text { Selecting the } \\
\text { geographical area }\end{array}$ & & & & & & & & & & & & & & & & & & & & \\
\hline & 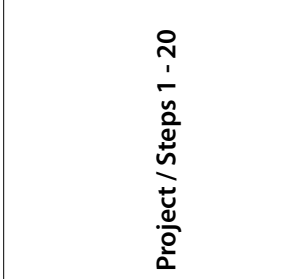 & 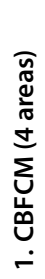 & 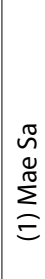 & 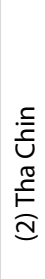 & 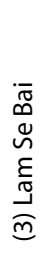 & 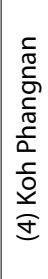 & 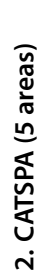 & 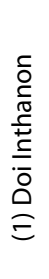 & 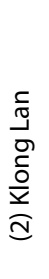 & 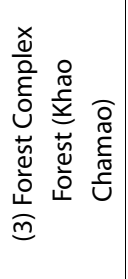 & 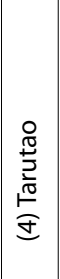 & 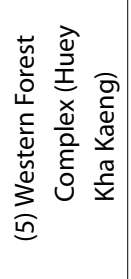 & 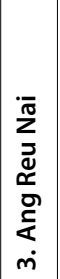 & 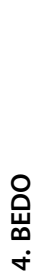 & 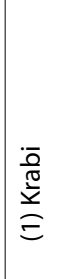 & 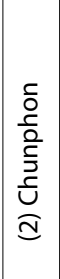 & 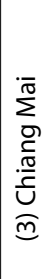 & 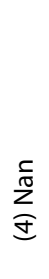 & 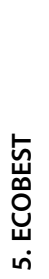 & 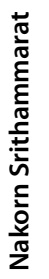 & 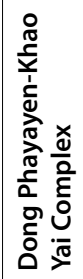 \\
\hline
\end{tabular}




\section{Legal framework for PES in Thailand}

There is at present no legal framework for PES in Thailand. There are laws that are relevant to the specific types of land that can potentially become PES sites. Almost all of the PES and PES-like projects are located on public land which are covered by different pieces of legislation such as: the National Park Act 1961, the National Forest Reserve Act 1964, the Wildlife Protection Act 1992, the Land Code 1954 and the Treasury Act 1975. There are also Ministerial Orders, Rules and Regulations, which highlight the rights, responsibilities, and restrictions on access to various types of public land and penalties for violation. The existing legal framework is not 'enabling' by nature. This means that if there were to be PES projects on 'public land', some amendments or exemptions would have to be made to allow service providers to carry out measures in public areas where there are legal entry restrictions. The 11th National Economic and Social Development Plan acknowledgement the value of PES as a possible solution and a natural resources management option. There are institutional' interests from international organizations such as WWF, IUCN and ECOBEST on the use of economic instruments to create incentives for natural resources conservation and improvement of environmental quality.

\subsection{Laws related to the areas that are the sources of ES}

These laws have been designed to protect natural resources. The stipulations in these laws aim to prohibit access and penalize noncompliance.

\subsubsection{National Parks Act 1961}

The National Parks Act provides for the establishment of both terrestrial and marine national parks for biodiversity conservation. Entry on a visitor basis is allowed but other forms of use, such as residence, hunting, clearing, gathering of vegetation, mining and the introduction of livestock, are prohibited.

\subsubsection{Wildlife Preservation and Protection Act 1992}

The Act was enacted in 1960 with the objective of conserving and protecting wildlife, expanding wildlife breeding and ensuring that wildlife protection and conservation measures are in accordance with international agreements. The Act also stipulates rules governing the hunting and trade of wild animals and lists a number of protected species. The Act was amended in 1992 to provide for the establishment of wildlife sanctuaries as primarily wildlife conservation areas under the jurisdiction of the DNP. No forms of residence or extractive use are allowed within wildlife sanctuaries. Entry is restricted and is for education and research purposes and this is subject to notification of authorities.

\subsubsection{National Forest Reserve Act 1964}

The objective is to protect the state of the forest and natural resources within the forest by designating areas as National Forest Reserves and other areas where utilization is permitted. The amendment of this Act in 1992 resulted in the classification of national forest reserves into three zones, i.e. conservation forests, economic forests and agricultural-use forests. By definition, conservation forests cover protected areas and areas of ecological importance such as Class I watersheds. Access and utilization is permitted for economic forests, which are used for commercial forestry. Agricultural-use forests are mainly degraded forest areas, which over the years have been allocated to landless farmers and those within sufficient land under the Agricultural Land Reform Programme.

\subsection{Laws that will justify the potential role of local communities}

There are legal frameworks, which by defining the rights and entitlements of individuals to natural resources, can be used as a reference to justify roles of individuals or groups of individuals as service providers. Section 66 of the Constitution of the Kingdom of Thailand, 2007 stipulates that:
persons so assembling as to be a community, a local community or a traditional community shall have the right to conserve or restore their customs, local knowledge, good arts and culture of their community and of the nation and participate in the management, maintenance, preservation and exploitation of natural resources, the environment and the biological diversity in a balanced and sustainable fashion.

The principle of the Enhancement and Conservation of National Environmental Quality Act, 1992 is consistent with the principle of Section 66 of the Constitution. The intentions of the Enhancement and Conservation of National Environmental Quality Act, 1992 is to promote the participation of the general public and private 
sector in maintaining and improving the quality of the environment. The goal is to ensure that environmental management is in accordance with the principle of environmental quality management.

\subsection{Is there a need for a PES law?}

If the starting point is to pass a PES law, then it will be a long-drawn-out process. One has only to look at the two recent cases. One was the Community Forest Management Bill. In 2000, the Thai parliament passed the Draft Community Forest Management Bill but it was later rejected by the senate, and along with it any hope that the status of communities living in and around Thailand's national forest reserves would be legally recognized or that community forests could be managed by local communities in cooperation with the Royal Forestry Department. The Bill is still pending. The other is the Draft Bill on the Use of Economic Instruments, which was rejected by the Ministry of Finance even before it reached parliament.

But while passing a law is a lengthy process, the policy on watersheds has at least shown some success. In the late 1970s the primary concern was to relocate hill tribes out of the forests; this changed into integrated watershed management in the 1980s. From the 1990s onwards, the role of local people's participation became more important and the idea of 'watersheds for the people', which includes greater community participation and the concept of benefitsharing, was introduced. The policy framework is supportive and there are laws that recognize the role of local communities in natural resources management, which can be used as references for 'relaxing' the restrictions imposed by the laws that aim primarily to protect natural resources.

\subsection{Stakeholders}

\subsubsection{Public agencies at the policy level}

\section{A. Office of National Economic and Social Development Board (NESDB) \\ The NESDB is mandated as a macro-level planning body responsible for formulating the 5-year social and economic development plans. Within the present plan, which covers the period from 2012 to 2016, PES is recognized as an instrument for creating incentives for natural resources conservation. Beyond this statement in}

the $11^{\text {th }}$ Plan, representatives of the NESDB have participated in several forums mainly to discover who is involved in PES projects, and where.

\section{B. Office of Natural Resources and Environmental Policy and Planning (ONEP)}

ONEP, MONRE is a public agency whose involvement is limited primarily to the policy level. As it is secretariat to the National Environmental Board (NEB) and the agency responsible for coordination of natural resources management issues, it could play a greater role in advocating PES. The mandate of one of the three divisions within ONEP, the environmental quality management sector, is to monitor, control, supervise and promote incentives for prevention and remedy of environmental problems. This division is responsible for the management of Thailand's environmental fund. ONEP formulated the National Policy, Measures and Plans on the Conservation and Sustainable Utilization of Biological Diversity (1998-2002), which is the principal framework for biodiversity conservation and management in Thailand. Issues related to biological resources such as PES will be of direct relevance to ONEP, particularly the regional environmental management sector, which is responsible for the management of biological resources.

\subsubsection{Public agencies at implementation level}

\section{A. Department of National Parks, Wildlife and Plant Conservation (DNP)}

The DNP is a public agency that will play a key role in supporting the concept of PES in Thailand for two main reasons. First, most of the environmental and biodiversity hotspots are located within terrestrial or marine parks, making the role of DNP an essential component of PES projects. Second, DNP is interested in developing an effective instrument for protection, restoration and conservation of natural resources. PES as a concept is consistent with the DNP's key strategy to adopt participatory approaches to integrated watershed management, including improving the economic welfare of people living in watersheds.

\section{B. Regional environment offices (REOs)}

REOs are the main counterparts of the ongoing PES project under the CBFCM project. Each $\mathrm{REO}$ is mandated to play a coordinating role among provincial governments and other relevant government agencies, including the Royal Department of Forestry and the DNP for effective 
environmental management. There are $16 \mathrm{REOs}$ and four are now acting as CBFCM project counterparts in the four PES pilot project sites.

\section{Department of Marine and Coastal Resources (DMCR)}

The DMCR will play a key role in PES projects that involve conservation of coastal and marine resources such as Tarutao site (CATSPA) and Phangan Island site (CBFCM). DMCR and the MONRE were both established in 2002. The vision of the department is: "marine and coastal resources are managed for prosperity and sustainability" and the mission is: "to specify a coastal resources policy, plan and management based on good governance for the prosperity and sustainable utilization."

The DMCR has eight principle mandates, to

- submit the review, amendment on rules, regulations and measures related to the conservation, rehabilitation, management and utilization of marine and coastal resources;

- supervise, evaluate and monitor activities to comply with the rule, regulation and measures;

- study, research, develop conservation and rehabilitation of marine and coastal resources including plants and marine endangered species;

- propose appropriate conservation sites for the preservation, protection and monitoring of marine and coastal resources;

- promote and enhance the understanding and participation of people in the conservation of marine and coastal resources;

- establish an information center of marine and coastal resources in Thailand;

- coordinate among national and international organizations in the area of marine and coastal resources;

- act on any other regulation for the duties of the department or as assigned by the minister or the cabinet.

\section{Biodiversity-based Economy Development Organization (BEDO)}

BEDO was established in 2007 to promote conservation of biodiversity resources, improve local community knowledge of best practice for biodiversity and enhance biodiversity-based economy development. The concept of PES was adopted in the organization's 5-year strategic plan (2007-2011) as a means to enable its work on developing sustainable production of biodiversity-based products. The use of PES concepts was included as a strategic priority in BEDO's next 5-year strategic plan (2012-2017), as evidenced by the five PES projects initiated and progressed to various stages discussed in this report.

\subsubsection{International agencies}

\section{A. United Nations Development Programme (UNDP)}

UNDP is the most involved organization in PES as it is the organization that receives funding from the GEF to finance the PES pilot projects both under CATSPA and CBFCM project frameworks.

\section{B. WWF-IUCN}

WWF's involvement is through the Strengthening Andaman Marine Protected Area Network (SAMPAN), a three-year project supported by Agense Francaise de Developpement (AFD) and Fonds Francais pour l'Environnement Mondial (FFEM). Under SAMPAN, WWF through IUCN has commissioned a study to examine the sustainable financing strategies for three marine protected areas in the Andaman Seas: Lanta, Surin and Similans Marine National Park. (Nabangchang et al. 2012) The concept of PES is linked to the design of economic instruments. However, apart from the launch by WWF Thailand of the 'Reef Guardian' campaign which involved some voluntary payments, there have been no efforts by WWF, IUCN or DNP to follow-up on recommendations to adopt some of the economic instruments proposed. Nevertheless, this study should be valuable for current efforts to design PES projects located in marine and coastal environmental hotspots and island ecosystems such as Tarutao Island (CATSPA project) and Phangan (CBFCM project).

\section{Enhancing the Economics of Biodiversity and Ecosystems in Thailand/Southeast Asia (ECOBEST)} The principle of ECOBEST is to demonstrate that biodiversity conservation and protecting valuable ecosystems makes financial and economic sense, and that unless this is recognized, there will be overconsumption and under investment in protection and conservation measures. ECOBEST is a 5-year program (2011-2015) co-funded by the EU, the German Government and Helmholtz Centre for Environmental Research. In addition, co-funding is provided from the RTG through DNP.

ECOBEST is launching PES projects in two sites (Dong Phrayayen and Nakhon Sri Thammarat) with the aim of generating the experiences and lessons learned which are valuable inputs for drafting revising legislation on the use of economics and financial tools for Thailand, which 
is one of the organization's mandates. One of the expected results is long-term funding and actions for economics and financial tools mainstreamed in ASEAN and GMS institutions.

ECOBEST has been active in linking policy makers, implementing agencies, non-governmental organizations (NGOs) and academics that are working on PES or related activities. It is one of the expected results that lead to the establishment of 'competence centers for ES'.

Training courses have been offered as part of its capacity-building mandate, with participants from the private sector, public agencies, NGOs and academics.

\section{Thailand Environmental Institute (TEI)}

TEI can potentially contribute to the advancement of the PES concept due to its involvement in the activities of The Economics of Ecosystems and Biodiversity in Thailand which is advocated by ECOBEST. TEI is a non-profit organization and is recognized as one of the main research institutes in Thailand. It has a close relationship with the private sector primarily because it has been instrumental in advocating the concept of eco-labeling. ECOBEST collaborated with TEI in organizing what was planned to be a series of training courses on the concepts and design of PES projects for the private sector. In principle, this will be way of creating 'recognition' of the benefits of ES.

TEI has undertaken studies that can be used in the design of PES projects. The focus of these studies was on estimating the economic value of ES. The first was in the Nam Yao-Auan and Muab watershed in Nan province. The focus of this project was to develop a greater awareness of the importance of ES, particularly resources that are 'non-marketed'. Translating these benefits into their equivalent market values shows that the value of ES can be as much as 1.7 times more than the market value of maize. The project examined the external costs of converting forests into maize cultivation and different scenarios projecting for the next 5 years. It was recommended that a Nan River Basin Fund be established although it is unclear whether this will be used as a seed fund to start off conservation activities under a PES scheme. Two other studies were conducted: the study of the benefits of non-timber forest products of the Ban Dong villagers in Phitsanulok province; and estimation of market values of fisheries in Kaper Bay, Rayong province.

\subsection{Concluding observations}

Although its environmental resource management strategies may lag behind other countries in the region, Thailand has benefited from the PES experiences of other countries. The ongoing projects, although at their early stages, have already demonstrated the complexities involved and stakeholders are starting to learn the processes. Some key observations on the PES experiences in Thailand are discussed below.

a. The existing legal framework, although not explicitly endorsing the concept of creating incentives for service providers (particularly local communities), can be relaxed in specific cases if this would enable the implementation of pilot projects. Anticipating criticisms that PES can be used as a tool for legitimizing occupants in protected areas, it must be made clear that payment is conditional, in the case of paying rewards for providing the services, and in the case of compensation for changing practices that will result in reducing the harm to environmental services. The fact that service providers are involved does not in any way increase their entitlement to property rights to land, or rights of access to natural resources.

b. There is room for sharing experiences among the ongoing PES projects particularly the pilot projects under CATSPA and CBFCM who have the same source of funding (UNDP-GEF). So far ECOBEST has tried to bring together those who are involved in the various projects.

c. There is also room for sharing study outputs. For example, it is likely that the results of the ARNWS PES pilot project will be used for the Khao Chamao site, which is one of the sites under CATSPA, located in the Eastern Forest Complex. This is because ARNWS and Khao Chamao were part of the same forest complex but has become over the years fragmented because of encroachment.

d. There is need for capacity building and information sharing. As all parties involved have no prior experience, it would be more efficient to jointly organize capacity-building programs for different skills and different steps in the PES process.

e. One of the major challenges is to create recognition of the benefits from ES. Among the lessons learned from ARNWS pilot project is that private companies may place more weight on quick, tangible results. Clearly, there is a need for a formal institutional framework to create tangible incentives for the private sector to be involved and to do this, it may 
be strategically better to approach the 'private sector institution' such as: the Federation of Thai Industries and the Thai Chamber of Commerce, rather than individual private companies. To create demand on a scale that would give the momentum for PES both for ARNWS and for other potential PES sites in Thailand would require a revamp of the legal tools which already exist to create effective demand for conservation services in the same way that the BioBanking scheme was established for New South Wales. In the absence of strategic and innovative approaches to the private sector, CSR investment is likely to be spread so thin while succeeding in promoting publicity of private companies, with little tangible outcomes in improving the environment.

f. There is need for capacity building. Training programs should be target-group specific for stakeholders from the national level down to local community level. Training needs for those who are involved as counterparts in both CATSPA and CBFCM projects are critical. This is because unless there is an understanding of PES concepts and the complexities involved, they are unlikely to perform the supporting role required of them. One issue that must be clarified is that designing PES projects requires inputs from multiple disciplines, including economics. From the limited experiences of PES in Thailand, some suggest that economists can single-handedly design PES projects while others think it is not necessary for economists to be involved as long as someone in the team knows how to do economic valuation. While the latter may be true, it is easy to do PES badly and as economic valuation to support the design of PES projects is an essential input, it must be done correctly.

g. Some of the projects discussed in this report, although called PES projects, are essentially a modified form of CSR. There is nothing wrong with CSR projects but CSR activities do not address missing markets, or aim to create incentives to undertake conservation measures on a sustainable basis.

h. As in many other countries where the PES concept has been adopted, there is potential for poverty alleviation given that there is an observed concentration of poor and resource-dependent communities in many environmentally sensitive areas. With an estimated number of forestdependent people of 1-2 million people, the magnitude of the problem is large and there is a degree of urgency to finding some kind of solution $^{3}$. All PES sites were selected based on their biophysical conditions. Although poverty alleviation was not the determining factor for site selection, income effect is an expected outcome of all projects. How much income effect these projects might have would depend on the attention given to the implementation of Steps 11 (estimating the individual marginal costs of ES supply) and Step 13 (selection of ES suppliers). Much also depends on the design of the payment system (Step 12) and the payment transfer system (Step 15), since both of these would ensure transparency of funds management. Few, if any, of Thailand's PES projects have reached these steps, and for some of those where monetary payments have been paid, the time lag is not yet sufficient to conclude whether there has been any significant income impact.

i. There is potential to adopt PES as a tool for biodiversity conservation, and there is a critical need for PES. At present, biodiversity conservation in Thailand relies heavily on legal measures. Without effective control measures, various pieces of legislation cited earlier have their limitations. Implementing agencies will never have sufficient resources to protect natural resources. Overexploitation of biodiversity resources, like all public goods, is due to the failure to recognize that the economic value exceeds the market prices of the tradable parts of biodiversity resources. Unless there is recognition of the non-tradable benefits of biodiversity resources, the benefits gained will continue to be underpriced. PES can be instrumental as a tool for biodiversity conservation, as the design of PES projects is mainly about creating recognition of the benefits, demonstrating the economic values and capturing the value of the benefits.

\section{References}

Biodiversity-Economy Based Development Organization. 2013. The economic values of ecosystems services from mangroves: Krabi Province. Bangkok: BEDO (in Thai).

Carbon2Markets Program. 2009. Carbon2Markets: Small-Holder Agroforestry Project Thailand-Teak Project Report.

Jarungrattanapong R, Mahasuweerachai $\mathrm{P}$ and Nabangchang O. 2004. Payment for Ecosystem

3 Based on estimates of the Regional Forestry Training Center 
Services for Thailand and Lao PDR. Penang, Malaysia: Economy and Environment Program for Southeast Asia.

Nabangchang O. 2009. An analysis of economic values of Inthanon National Park. Bangkok: Department of National Park, Wildlife and Plant Conservation.

Nabangchang O and Srisawalak E. 2011. Ang Rue Nai Wildlife Sanctuary PES Pilot Project. Bangkok: BEDO.

Nabangchang O, Seenprachawong U, Janamporn S, Suthat K, Thongsopin K and Marchant R. 2012. Sustainable financing strategy for Lanta, Surin and Similans Marine National Park. Emerton L, ed.

Scheufele G, Bennette J, Kragy M and Renton M. 2014. Development of a virtual PES scheme for the
Nam Ngum River Basin. Effective implementation of payment for environmental services in Lao PDR. A project commissioned to the Australian National University by the Australian Centre for International Agricultural Research (ACIAR). Research Report No. 3.

Wanghongsa S, Boonkird K, Senatham Y, Saengsen D and Cocharee Y. 2006. The death of elephants in Khao Ang Rue Nai Wildlife Sanctuary between 1996 and 2006. Wildlife Yearbook. 7:132-46 (in Thai).

Wunder S, Engel S and Pagiola S. 2008. Taking stock: A comparative analysis of payments for environmental service programs in developed and developing countries. Ecological Economics 65(4):834-52. 

CIFOR Working Papers contain preliminary or advance research results on tropical forest issues that need to be published in a timely manner to inform and promote discussion. This content has been internally reviewed but has not undergone external peer review.

Thailand is somewhat lagging behind other countries in Southeast Asia in adopting the concept of payment for environmental services (PES) as an instrument for creating incentives for natural resources conservation. There are a number of activities involving payments for provision of activities or environmental services but these are missing many elements that would qualify them as a PES project. Others are mainly at the design stage or at the initial stages of implementation.

One of the major challenges is to create recognition of the benefits from ecosystems services. Presently, private sectors attach considerable importance to CSR projects. There is nothing wrong with CSR projects but CSR activities do not address missing markets, nor aim to create incentives to undertake conservation measures on a sustainable basis. To create demand on a scale that would give the momentum for PES would require a revamp existing legal tools to create effective demand for conservation services. It may be strategically better to approach the 'private sector institution' such as: the Federation of Thai Industries and the Thai Chamber of Commerce, rather than individual private companies. Without this, CSR investment is likely to be spread so thin and while succeeding in promoting publicity of private companies, tangible outcomes in improving the environment are likely to be limited.

Although biophysical conditions precede other criteria for selection of potential PES project sites, given that there is an estimated number of forest-dependent people of 1 to 2 million people most of whom believed to be poor and living in environmentally sensitive areas, it is undeniable that PES can be instrumental to addressing poverty alleviation objectives. A major challenge that must be addressed however, is the legal framework. Although not explicitly endorsing the concept of creating incentives for service providers, the relevant laws can be, -and needs to be-, relaxed in specific cases, particularly where PES types projects will be launched in protected areas where there are legal restrictions over access.

PES can also supplement the legal provisions to protect biodiversity resources. Like all public goods, over-exploitation of biodiversity resources, is due to the failure to recognize that the economic value exceeds the market prices of the tradable parts of biodiversity resources. Unless there is recognition of the non-tradable benefits, biodiversity resources will continue to be underpriced and under valued, hence the potential contribution of the concept of PES projects to create recognition, demonstrate its economic values and link between the demand and supply side to capture those values.

RESEARCH PROGRAM ON

Forests, Trees and Agroforestry
This research was carried out by CIFOR as part of the CGIAR Research Program on Forests, Trees and Agroforestry (CRP-FTA). This collaborative program aims to enhance the management and use of forests, agroforestry and tree genetic resources across the landscape from forests to farms. CIFOR leads CRP-FTA in partnership with Bioversity International, CATIE, CIRAD, the International Center for Tropical Agriculture and the World Agroforestry Centre.

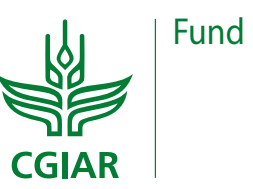

